\title{
Localized Corrosion Characteristics of Nickel Alloys: A Review
}

\author{
Helmuth Sarmiento Klapper ${ }^{1}$ Natalia S. Zadorozne ${ }^{2} \cdot$ Raul B. Rebak $^{3}$
}

Received: 24 January 2017/Revised: 18 February 2017/Published online: 2 March 2017

(C) The Chinese Society for Metals and Springer-Verlag Berlin Heidelberg 2017

\begin{abstract}
There are a great variety of commercial nickel alloys mainly because nickel is able to dissolve a large amount of alloying elements while maintaining a single ductile austenitic phase. Nickel alloys are generally designed for and used in highly aggressive environments, for example, those where stainless steels may experience pitting corrosion or environmentally assisted cracking. While nickel alloys are generally resistant to pitting corrosion in chloride-containing environments, they may be prone to crevice corrosion attack. Addition of chromium, molybdenum and tungsten increases the localized corrosion resistance of nickel alloys. This review on the resistance to localized corrosion of nickel alloys includes specific environments such as those present in oil and gas upstream operations, in the chemical process industry and in seawater service.
\end{abstract}

KEY WORDS: Nickel alloys; Localized corrosion; Oil and gas; Seawater; Chemical process industry

\section{Introduction}

Nickel (Ni) is a popular metallic element since it is used as a component in hundreds of alloys; it is used as a corrosion-resistant plating product and also as a catalyst. Approximately $61 \%$ of the Ni produced worldwide is used in the fabrication of stainless steels, which contain by weight approximately $10 \% \mathrm{Ni}[1]$. Only about $12 \%$ of the world production of $\mathrm{Ni}$ is used in the fabrication of $\mathrm{Ni}$ alloys or Ni-rich alloys. Over $90 \%$ of Ni-containing

Available online at http://link.springer.com/journal/40195.

Helmuth Sarmiento Klapper

Helmuth.sarmiento-klapper@bakerhughes.com

1 Center for Materials Research, Baker Hughes, 29221 Celle, Germany

2 Instituto de Materiales de Misiones (IMAM), UNaM, CONICET, 3300 Posadas, Argentina

3 GE Global Research, Schenectady, NY 12309, USA products are recycled at the end or their useful life, and there are no limits how many times the Ni metal can be recycled.

$\mathrm{Ni}$ alloys are solid solutions of the element $\mathrm{Ni}$ and other alloying elements. In general, the minimum amount of $\mathrm{Ni}$ in these alloys is in the order of $50 \%$ by mass; however, some alloys, such as alloy 904L (UNS N08904), alloy 800 (UNS N08800) and alloy 28 (UNS N08028), are classified in the family of $\mathrm{Ni}$ alloys even though they may contain less than 35\% Ni. Large percentages of alloying elements can be added to Ni to produce a vast variety of alloys, and some of these alloys are tailored for specific applications [1]. The resulting Ni alloys still maintain the face-centered cubic (fcc), gamma or austenitic single phase microstructure of pure Ni. In contrast, iron (Fe) alloys, i.e., austenitic stainless steels, cannot dissolve as much alloying elements as $\mathrm{Ni}$ without precipitating secondary phases. For example, Fe can accommodate as a maximum approximately $6 \%$ of molybdenum (Mo) in solid solution, while Ni can dissolve up to $30 \%$ Mo and still maintain an fcc single phase ductile microstructure. This has obvious consequences on the localized corrosion resistance of $\mathrm{Ni}$ alloys since $\mathrm{Mo}$ is well 
known for having a beneficial effect on the localized corrosion resistance of passive metals by improving their repassivation ability [2].

The list of commercial Ni alloys is being revised continuously since almost every other year a new alloy seems to appear in the market. Most, if not all the newer alloys, though, are modifications of previously existing alloys and their development and commercialization are result of research at a limited group of international primary metal producers of $\mathrm{Ni}$ alloys. A detailed review on the historical development of $\mathrm{Ni}$ alloys was done in the past by Agarwal and Kloewer [3]. The commercially produced $\mathrm{Ni}$ alloys in general are classified into two large groups: corrosion-resistant alloys (CRA) targeted for wet or condensed aqueous systems applications and superalloys or high-temperature alloys (HTA) targeted for applications in dry or gaseous corrosion systems. Tables 1 and 2 include representative Ni-based CRA and HTA, respectively. A CRA is understood in this document as an alloy that is resistant to general and localized corrosion in a variety of corrosive environments to carbon and stainless steels. However, the corrosion resistance intrinsically included in the term CRA should not be understood as immunity against any type of corrosion. The not well-defined temperature boundary of application between the CRA and the HTA is approximately $1000{ }^{\circ} \mathrm{F}\left(538^{\circ} \mathrm{C}\right)$. This CRA/HTA classification does not preclude that CRA may be used at temperatures higher than $538{ }^{\circ} \mathrm{C}$ and vice versa. Generally, the CRA are mostly selected for their capacity to resist corrosion in a given environment and less importance may be given to their mechanical strength. Nevertheless, most HTA need to play a dual role, that is, besides their capacity to withstand the aggressiveness of the high-temperature corrosive environment, HTA also need to keep significant strength at high temperatures [1]. On the other hand, some HTA alloys have been modified in terms of their chemical composition and age-hardening treatment to make possible their use as CRA in specific applications. Oil patch alloy 718 (UNS N07718) is a good example of this type of alloys.

Table 1 Nickel based corrosion-resistant alloys

\begin{tabular}{|c|c|c|c|}
\hline Alloy & UNS & Nominal approximate composition & Applications \\
\hline $\mathrm{Ni}-200$ & N02200 & $99 \mathrm{Ni}-0.2 \mathrm{Mn}-0.2 \mathrm{Fe}$ & Strong caustic environments \\
\hline $\mathrm{Ni}-301^{\mathrm{a}}$ & N03301 & $93 \mathrm{Ni}-4.5 \mathrm{Al}-0.6 \mathrm{Ti}$ & Fasteners, springs \\
\hline 400 & N04400 & $67 \mathrm{Ni}-31.5 \mathrm{Cu}-1.2 \mathrm{Fe}$ & Hydrofluoric acid, CPI \\
\hline $\mathrm{K}-500^{\mathrm{a}}$ & N05500 & $63 \mathrm{Ni}-30 \mathrm{Cu}-3 \mathrm{Al}-0.5 \mathrm{Ti}$ & Fasteners, springs, Oil and gas \\
\hline B-2 & N10665 & $72 \mathrm{Ni}-28 \mathrm{Mo}$ & Hot hydrochloric acid \\
\hline B-3 & N10675 & $68.5 \mathrm{Ni}-28.5 \mathrm{Mo}-1.5 \mathrm{Cr}-1.5 \mathrm{Fe}$ & Reducing acids \\
\hline B-4 & N10629 & $65 \mathrm{Ni}-28 \mathrm{Mo}-4 \mathrm{Fe}-1 \mathrm{Cr}-0.3 \mathrm{Al}$ & Hydrochloric and sulfuric acid \\
\hline C-276 & N10276 & $59 \mathrm{Ni}-16 \mathrm{Cr}-16 \mathrm{Mo}-4 \mathrm{~W}-5 \mathrm{Fe}$ & Versatile CPI and pollution control \\
\hline $625^{\mathrm{a}}$ & N06625 & $62 \mathrm{Ni}-21 \mathrm{Cr}-9 \mathrm{Mo}-3.7 \mathrm{Nb}$ & Aerospace, pollution control \\
\hline $\mathrm{C}-22$ & N06022 & $59 \mathrm{Ni}-22 \mathrm{Cr}-13 \mathrm{Mo}-3 \mathrm{~W}-3 \mathrm{Fe}$ & FGD, CPI, nuclear waste \\
\hline 2000 & N06200 & $59 \mathrm{Ni}-23 \mathrm{Cr}-16 \mathrm{Mo}-1.6 \mathrm{Cu}$ & CPI, oxidizing and reducing. Sulfuric acid \\
\hline 59 & N06059 & $59 \mathrm{Ni}-23 \mathrm{Cr}-16 \mathrm{Mo}-1 \mathrm{Fe}$ & Oxidizing and reducing acids, CPI \\
\hline 686 & N06686 & $46 \mathrm{Ni}-21 \mathrm{Cr}-16 \mathrm{Mo}-4 \mathrm{~W}-5 \mathrm{Fe}$ & Oxidizing and reducing acids, CPI \\
\hline $\mathrm{C}-22 \mathrm{HS}^{\mathrm{a}}$ & N07022 & $59 \mathrm{Ni}-21 \mathrm{Cr}-17 \mathrm{Mo}$ & Oil and gas \\
\hline Нy-BC & N10362 & $62 \mathrm{Ni}-15 \mathrm{Cr}-22 \mathrm{Mo}$ & Hydrochloric and sulfuric acid \\
\hline 600 & N06600 & $76 \mathrm{Ni}-15.5 \mathrm{Cr}-8 \mathrm{Fe}$ & Nuclear power \\
\hline 690 & N06690 & $58 \mathrm{Ni}-29 \mathrm{Cr}-9 \mathrm{Fe}$ & Nuclear power \\
\hline $718^{\mathrm{a}}$ & N07718 & $53 \mathrm{Ni}-19 \mathrm{Cr}-18 \mathrm{Fe}-5 \mathrm{Nb}-3 \mathrm{Mo}-1 \mathrm{Ti}-0.5 \mathrm{Al}$ & Oil and gas \\
\hline $716^{\mathrm{a}}$ & N07716 & $57 \mathrm{Ni}-21 \mathrm{Cr}-18 \mathrm{Fe}-8 \mathrm{Mo}-3.4 \mathrm{Nb}-1.4 \mathrm{Ti}-0.3 \mathrm{Al}$ & Oil and gas \\
\hline $725^{\mathrm{a}}$ & N07725 & $57 \mathrm{Ni}-21 \mathrm{Cr}-18 \mathrm{Fe}-8 \mathrm{Mo}-3.4 \mathrm{Nb}-1.4 \mathrm{Ti}-0.3 \mathrm{Al}$ & Oil and gas \\
\hline $\mathrm{X}-750^{\mathrm{a}}$ & N07750 & $73 \mathrm{Ni}-15 \mathrm{Cr}-7 \mathrm{Fe}-2.5 \mathrm{Ti}-1 \mathrm{Nb}-0.7 \mathrm{Al}$ & Nuclear power \\
\hline 825 & N08825 & $43 \mathrm{Ni}-21 \mathrm{Cr}-30 \mathrm{Fe}-3 \mathrm{Mo}-2.2 \mathrm{Cu}-1 \mathrm{Ti}$ & Oil and gas. Sulfuric and phosphoric acid \\
\hline $925^{\mathrm{a}}$ & N09925 & $44 \mathrm{Ni}-21 \mathrm{Cr}-22 \mathrm{Fe}-3 \mathrm{Mo}-2 \mathrm{Ti}-0.3 \mathrm{Al}-2 \mathrm{Cu}$ & Oil and gas \\
\hline $945^{\mathrm{a}}$ & N09945 & $50 \mathrm{Ni}-21 \mathrm{Cr}-18 \mathrm{Fe}-3 \mathrm{Mo}-3 \mathrm{Nb}-1.5 \mathrm{Ti}-0.3 \mathrm{Al}-2 \mathrm{Cu}$ & Oil and gas \\
\hline G-30 & N06030 & $44 \mathrm{Ni}-30 \mathrm{Cr}-15 \mathrm{Fe}-5 \mathrm{Mo}-2 \mathrm{Cu}-2.5 \mathrm{~W}-4 \mathrm{Co}$ & Nitric and phosphoric acid \\
\hline $\mathrm{T} 21$ & N06210 & $\mathrm{Ni}-19 \mathrm{Cr}-19 \mathrm{Mo}-1.8 \mathrm{Ta}$ & Resistant to localized attack \\
\hline
\end{tabular}

CPI Chemical Process Industry, ${ }^{\mathrm{a}}$ age hardenable 
Table 2 Nickel-based high-temperature alloys

\begin{tabular}{llll}
\hline Alloy & UNS & Approximate composition & Common high-temperature use \\
\hline 75 & N06075 & $78 \mathrm{Ni}-20 \mathrm{Cr}-0.4 \mathrm{Ti}$ & Gas turbines, heat treatment \\
230 & N06230 & $57 \mathrm{Ni}-22 \mathrm{Cr}-14 \mathrm{~W}-2 \mathrm{Mo}-0.3 \mathrm{Al}-0.02 \mathrm{La}$ & Gas turbines, super heater tubes \\
600 & N06600 & $75 \mathrm{Ni}-16 \mathrm{Cr}-9 \mathrm{Fe}$ & Furnace components \\
601 & $\mathrm{~N} 06601$ & $60 \mathrm{Ni}-23 \mathrm{Cr}-15 \mathrm{Fe}-1.4 \mathrm{Al}-0.3 \mathrm{Ti}$ & Furnace and heat treatment components, Combustion chambers \\
$\mathrm{X}$ & $\mathrm{N} 06602$ & $47 \mathrm{Ni}-22 \mathrm{Cr}-18 \mathrm{Fe}-9 \mathrm{Mo}-1.5 \mathrm{Co}-0.6 \mathrm{~W}$ & Combustion chambers, heat treatment components \\
617 & $\mathrm{~N} 06617$ & $55 \mathrm{Ni}-22 \mathrm{Cr}-12 \mathrm{Co}-9 \mathrm{Mo}-1 \mathrm{Al}$ & Gas turbine combustion cans, furnace components \\
625 & $\mathrm{~N} 06625$ & $62 \mathrm{Ni}-21 \mathrm{Cr}-9 \mathrm{Mo}-3.7 \mathrm{Nb}$ & Aerospace, pollution control equipment \\
214 & $\mathrm{~N} 07214$ & $75 \mathrm{Ni}-16 \mathrm{Cr}-4.5 \mathrm{Al}-3 \mathrm{Fe}-0.01 \mathrm{Y}$ & Specialized heat treatment, turbine parts \\
718 & $\mathrm{~N} 07718$ & $53 \mathrm{Ni}-19 \mathrm{Cr}-18 \mathrm{Fe}-5 \mathrm{Nb}-3 \mathrm{Mo}-1 \mathrm{Ti}-0.5 \mathrm{Al}$ & Gas turbines, rocket engines, nuclear applications \\
$\mathrm{X}-750$ & $\mathrm{~N} 07750$ & $72 \mathrm{Ni}-16 \mathrm{Cr}-7 \mathrm{Fe}-2.5 \mathrm{Ti}-1 \mathrm{Nb}-0.6 \mathrm{Al}$ & Gas turbine components, pressure vessels, applications in nuclear reactors \\
$800 \mathrm{HT}$ & $\mathrm{N} 08811$ & $31 \mathrm{Ni}-45 \mathrm{Fe}-21 \mathrm{Cr}-0.4 \mathrm{Al}-0.6 \mathrm{Ti}$ & Industrial furnaces, carburizing equipment \\
242 & $\mathrm{~N} 10242$ & $65 \mathrm{Ni}-25 \mathrm{Mo}-8 \mathrm{Cr}$ & Turbine seal rings, fasteners \\
160 & $\mathrm{~N} 12160$ & $37 \mathrm{Ni}-29 \mathrm{Co}-28 \mathrm{Cr}-2.75 \mathrm{Si}-2 \mathrm{Fe}$ & Thermocouple shields, calciner components \\
120 & $\mathrm{~N} 08120$ & $33 \mathrm{Fe}-37 \mathrm{Ni}-25 \mathrm{Cr}-0.7 \mathrm{Nb}-0.2 \mathrm{~N}$ & Carburizing and sulfidizing environments \\
282 & $\mathrm{~N} 07208$ & $57 \mathrm{Ni}-20 \mathrm{Cr}-10 \mathrm{Co}-8.5 \mathrm{Mo}-2.1 \mathrm{Ti}-1.5 \mathrm{Al}$ & Age hardenable with creep resistance \\
\hline
\end{tabular}

This paper is a compilation of data on localized corrosion resistance of $\mathrm{Ni}$ alloys including the work conducted at the former research laboratory of Prof. José Rodolfo Galvele [4-13] and other laboratories around the globe [14-42]. Most of the analysis and interpretation of the results obtained in these studies were based on Prof. Galvele's original publication entitled "Transport Processes and the Mechanism of Pitting of Metals" [43]. In 2016 we celebrated the 40th anniversary of the publication of Prof. Galvele work in the Journal of Electrochemical Society, which is among the 100 most cited papers in the history of the Journal. Prof. Galvele passed away in 2011.

\section{General Background}

$\mathrm{Ni}$ alloys are in general more corrosion resistant than austenitic stainless steels in a given industrial application. $\mathrm{Ni}$ alloys are also more expensive than stainless steels mainly because the base metal $\mathrm{Ni}$ is more expensive than $\mathrm{Fe}$, but also because the Ni alloys may hold a larger variety and amount of alloying elements, e.g., Mo, compared to stainless steels. Also, in many cases some Ni alloys products and components are not readily available from the market and may need to be especially ordered. Ni alloys were developed to fill a need in the industry, where highly corrosive streams and high-temperature environments exist. The main alloying element for $\mathrm{Ni}$ alloys is chromium $(\mathrm{Cr})$, which is added because it forms a chromium oxide $\left(\mathrm{Cr}_{2} \mathrm{O}_{3}\right)$ surface film at atmospheric conditions (passivation) that provides protection against further environmental degradation. The protection by chromium oxide is effective both in aqueous environments and in high-temperature gaseous environments. Two other common alloying elements used in CRA and HTA are Mo and tungsten (W). In the CRA, Mo and W provide resistance to general corrosion in reducing acids. The main applications for CRA are in the area of hot chloride solutions and hot acids.

One of the large advantages of $\mathrm{Ni}$ alloys over austenitic stainless steels is the resistance of $\mathrm{Ni}$ alloys to stress corrosion cracking (SCC), which chronically plagues the performance of the austenitic stainless steels in every industrial application. While Ni alloys are very resistant to chloride-induced stress corrosion cracking (SCC) by virtue of their high nickel content, austenitic stainless steels are very prone to SCC in hot chloride solutions [44]. Ni alloys have been also preferentially used in hot acids because they can dissolve larger amounts of beneficial alloying elements than iron. For example, the Ni alloy B-3 (UNS N10675) is highly resistant to corrosion in hot hydrochloric acid because it contains minimum $28.5 \%$ Mo (Table 1 ).

Tables 1 and 2 also list some important uses for the Nibased CRA and HTA, respectively. The uses and applications in Tables 1 and 2 are highly condensed. The types of degradation that the CRA alloys may undergo in service can generally be classified in three large groups: (1) general or uniform corrosion, (2) localized corrosion (pitting and crevice corrosion) and (3) environmentally assisted cracking (EAC), i.e., SCC, hydrogen embrittlement or corrosion fatigue. When selecting a material for an application, all the three main modes of degradation should be considered. Some CRA are targeted for highly specific environments 
since no other alloy performs as well in those conditions. For example, in highly caustic solutions $(>50 \% \mathrm{NaOH}$ at temperatures beyond $100{ }^{\circ} \mathrm{C}$ ), the best material is pure $\mathrm{Ni}$ (UNS N02200) and for hot reducing hydrochloric acid environments, the best alloys are B-2 (UNS N10665) or B-3 (UNS N10675). Also, for wet non-oxidizing hydrofluoric acid applications, the best alloy is Alloy 400 (UNS N04400). Other alloys such as Ni-Cr-Mo alloy C-276 (UNS N10276) were designed to be multipurpose alloys, that is, they perform reasonable well in multiple environments but are not the best one for each separate condition. As new alloys are developed to resist a certain environment, engineers generally adjust the conditions to become increasingly more aggressive, pushing the boundaries of the resistance of these alloys. Therefore, a more resistant alloy needs to be developed. That is, there is a continuous feedback relationship between alloy development and field performance.

\section{Localized Corrosion Resistance}

Localized corrosion may occur in passivating alloys, that is, in alloys containing enough $\mathrm{Cr}$ to form a protective passive film such as stainless steel and Ni alloys. Pitting corrosion develops as discrete surface spots, which experiment anodic dissolution while the rest of the surface remains passive and act as a large cathode [2]. Pitting corrosion occurs by metallic salt hydrolysis and subsequent formation of hydrochloric acid inside of the active spots as discussed in Galvele's local acidification pitting model [43]. The genesis of crevice corrosion is similar as for pitting corrosion and has to do with passivity breakdown. However, it is widely accepted that crevice corrosion is much more catastrophic than pitting due to the fact that when crevice corrosion nucleates, repassivation is very unlikely. Ni-Cr-Mo alloys like those included in Table 1 have the appropriate elements to offer outstanding resistance to pitting corrosion and crevice corrosion but are not immune against localized corrosion. It has been also demonstrated that nitrates can be used as inhibitors to avoid localized corrosion in $\mathrm{Ni}$ alloys [25].

\section{Influence of Alloying Elements}

One commonly used parameter to rate the resistance of alloys to localized corrosion at the industry is the pitting resistance equivalent (PRE). In general, the higher the PRE, the better the resistance of the alloy to localized corrosion. Equation (1) is the one of the relationships for calculating the PRE [45], where the symbols represent the mass fraction of selected alloying elements in the alloy. Other empirical relationships include different factors for quantifying the effect of Mo [46], N and W [47], and niobium (Nb) [37]. There are more equations for calculating PRE than experimental results that support a particular empirical correlation, but all of them are essentially the same.

$\mathrm{PRE}=\mathrm{Cr}+3.3(\mathrm{Mo}+0.5 \mathrm{~W})+16 \mathrm{~N}$.

Table 3 shows the typical PRE for Ni-based CRA that are used in environments that could cause localized corrosion or SCC. The use of PRE to rank Ni alloys is highly resisted in the scientific community since it was initially developed for stainless steels. It has been argued that the comparison is not fair due to the fact that $\mathrm{Ni}$ can dissolve, as aforementioned, more and higher amounts of alloying elements than iron. The solubility of nitrogen $(\mathrm{N})$ in Ni alloys, in contrast, is much lower than in stainless steels. Therefore, its contribution to the PRE is much lower in Ni alloys than in stainless steels. According to Eq. (1), $\mathrm{Cr}$, Mo and $\mathrm{W}$ contribute to the PRE. There is general consensus that $\mathrm{Cr}$ controls passive film formation and breakdown potential but does not affect the repassivation behavior of $\mathrm{Ni}$ alloys. On the other hand, it is believed that $\mathrm{Mo}$ and $\mathrm{W}$ contribute to the repassivation ability of $\mathrm{Ni}$ alloys after pit initiation [14, 15, 20]. Gruss et al. [15] used cyclic potentiodynamic polarization tests to compare the repassivation potential of alloys 825 (UNS N08825), 625 (UNS N06625), and 22 (UNS N06022). They reported an increase in the repassivation potential values as the calculated PRE increased following the order: alloy 825 $<$ alloy $625<$ alloy 22 . The amount of $\mathrm{Cr}$ in alloys 625 and 22 is similar; however, alloy 22 has a superior resistance to localized corrosion because of its higher Mo content (Table 3). Mishra et al. [29] compared the crevice initiation and repassivation potentials of alloys C-276 and 686 (UNS N06686), which have similar contents of Mo and W but 16 $\mathrm{wt} \% \mathrm{Cr}$ and $21 \mathrm{wt} \% \mathrm{Cr}$, respectively. The authors concluded that while $\mathrm{Cr}$ affected the critical crevice temperature and the potential for crevice corrosion initiation, once initiated, the localized corrosion process at the crevice site, $\mathrm{Cr}$ content had little effect on the repassivation potential. Hayes et al. [23] studied different $\mathrm{Ni}-\mathrm{Cr}-\mathrm{Mo}-\mathrm{Fe}$ alloys and concluded that the pitting repassivation potential was a function of Mo content. It has been also shown that the repassivation potential of $\mathrm{Ni}-$ Cr-Mo alloys increased with the PRE [8, 12]. However, this increase was more a function of Mo since for high Mo alloys the contribution of this alloying element to the PRE is more significant than that of $\mathrm{Cr}$ (Eq. 1). Therefore, $\mathrm{Cr}$ is necessary in the alloy to form a protective passive film, but once the passivation is destroyed and localized corrosion gets established as discrete spots with a low-pH solution inside the pits, the presence of Mo in the alloy is the crucial element that controls a rapid repassivation. 
Table 3 CPT and CCT for selected Ni alloys in different testing environments (Env)

\begin{tabular}{|c|c|c|c|c|c|c|c|c|c|c|c|c|}
\hline \multirow[t]{2}{*}{ UNS } & \multicolumn{3}{|c|}{ Element $(\mathrm{wt} \%)^{\mathrm{a}}$} & \multirow[t]{2}{*}{$\mathrm{PRE}^{\mathrm{b}}$} & \multicolumn{4}{|c|}{$\mathrm{CPT}\left({ }^{\circ} \mathrm{C}\right)$} & \multicolumn{4}{|c|}{$\mathrm{CCT}\left({ }^{\circ} \mathrm{C}\right)$} \\
\hline & $\mathrm{Cr}$ & Mo & W & & Env $1^{\mathrm{c}}$ & Env $2^{\mathrm{d}}$ & Env $3^{\mathrm{e}}$ & Env $4^{\mathrm{f}}$ & Env $1^{\mathrm{g}}$ & Env ${ }^{\mathrm{d}}$ & Env $3^{\mathrm{e}}$ & Env $4^{\mathrm{f}}$ \\
\hline N07718 & 17.0 & 2.8 & & 26 & 45 & 45 & & & $<10$ & & $\leq 25$ & \\
\hline N08825 & 19.5 & 2.5 & & 28 & 30 & & 25 & & 5 & & -5 & \\
\hline N09925 & 19.5 & 2.5 & & 28 & 35 & & & & & & & \\
\hline N09946 & 19.5 & 3.0 & & 29 & 45 & & & & & & & \\
\hline N07716 & 19.0 & 7.0 & & 42 & $>85$ & & & & & & 35 & \\
\hline N07725 & 19.0 & 7.0 & & 42 & $>85$ & 75 & & & 25 & & & \\
\hline N06625 & 20.0 & 8.0 & & 46 & $>85$ & 75 & 90 & 41 & 35 & 85 & 50 & \\
\hline N06022 & 20.0 & 12.5 & 2.5 & 65 & $>85$ & 120 & 150 & & 75 & 105 & 102 & \\
\hline N10276 & 14.5 & 15.0 & 3.0 & 69 & $>85$ & 105 & 150 & 83 & 50 & 105 & 80 & \\
\hline N07022 & 20.0 & 15.5 & & 71 & $>85$ & $>120$ & & & 100 & & & \\
\hline N06059 & 22.0 & 15.0 & & 72 & $>85$ & $>120$ & & 100 & & 110 & & \\
\hline N06686 & 19.0 & 15.0 & 3.0 & 73 & $>85$ & $>120$ & & & & 110 & & \\
\hline
\end{tabular}

${ }^{a}$ Minimum values in mass percent according to SAE-ASTM

b According to Eq. (1)

c According to ASTM G48 Method $\mathrm{C}$ in $6 \% \mathrm{FeCl}_{3}+1 \% \mathrm{HCl}$ [48]

d $11.5 \% \mathrm{H}_{2} \mathrm{SO}_{4}+1.2 \% \mathrm{HCl}+1 \% \mathrm{FeCl}_{3}+1 \% \mathrm{CuCl}_{2}$

e $4 \% \mathrm{NaCl}+0.1 \% \mathrm{Fe}_{2}\left(\mathrm{SO}_{4}\right)_{3}+0.01 \mathrm{~mol} / \mathrm{L} \mathrm{HCl}$

f $4.5 \mathrm{~mol} / \mathrm{L} \mathrm{CaCl}_{2}$ [17]

g According to ASTM G48 Method D in $6 \% \mathrm{FeCl}_{3}+1 \% \mathrm{HCl}$

The effect of copper $(\mathrm{Cu})$ on the localized corrosion of $\mathrm{Ni}-\mathrm{Cr}-\mathrm{Mo}$ alloys in hot saline solutions has been investigated by Mishra et al. [42]. By comparing the crevice corrosion resistance of alloys 59 (UNS N06059) and 2000 (UNS N06200), it was demonstrated that crevice initiation is retarded on the $1.6 \mathrm{wt} \% \mathrm{Cu}$-containing alloy 2000 compared to the $\mathrm{Cu}$-free alloy 59. Both alloys have similar $\mathrm{Cr}$ and Mo contents (Table 3). The tests were using a galvanostatically controlled single crevice assembly in $1 \mathrm{~mol} / \mathrm{L} \mathrm{NaCl}$ solutions at different temperatures. Copper, nevertheless, has not been included yet in any equation used for determining the PRE of Ni alloys.

Besides PRE, the resistance to localized corrosion of $\mathrm{Ni}$ alloys is typically rated at the industry by the critical pitting and crevice temperatures. These are the minimum temperatures to initiate pitting and crevice attack in one particular alloy. Several environments have been used for determining these parameters. ASTM G48 [48] describes immersion tests in acidified ferric chloride solution for determining the critical pitting temperature (CPT) and the critical crevice temperature (CCT) of Ni alloys in practices $\mathrm{C}$ and $\mathrm{D}$, respectively. However, other environments have been also used. Table 3 includes CPT and CCT values for several $\mathrm{Ni}$ alloys in different test environments mainly reported by primary metal producers of $\mathrm{Ni}$ alloys. One significant drawback of the test solutions typically used for determining these parameters is their limited thermal stability at elevated temperatures. For example, the maximal test temperature in the ferric chloride solution is $85^{\circ} \mathrm{C}$ [48]. The test solution containing $11.5 \% \mathrm{H}_{2} \mathrm{SO}_{4}+1.2 \%$ $\mathrm{HCl}+1 \% \mathrm{FeCl}_{3}+1 \% \mathrm{CuCl}_{2}$ also called green death decomposes chemically above $120{ }^{\circ} \mathrm{C}$. Therefore, results that reports critical temperatures beyond $120^{\circ} \mathrm{C}$ in this environment are meaningless $[17,36]$. On the other hand, as shown in Table 3, highly alloyed Ni-Cr-Mo alloys do not exhibit pitting corrosion at temperatures below $120^{\circ} \mathrm{C}$ and cannot be ranked using these environments (Table 3). Therefore, electrochemical techniques are preferred for benchmarking $\mathrm{Ni}$ alloys regarding localized corrosion resistance at high temperatures $\left(T>120^{\circ} \mathrm{C}\right)[35,49]$.

A quick look at the results included in Table 3 confirms that crevice corrosion susceptibility is more critical than pitting on Ni alloys. Values for CCT are by far lower when compared to CPT values of the same alloy, particularly in the ferric chloride test solution. CCT values obtained in the green death solution, however, are only slightly lower than the corresponding CPT values for a given alloy. This demonstrates that the chemical composition, i.e., the redox potential of the selected test solution, significantly affects the results. Even though high CPT and CCT values correspond to alloys having higher PRE, a unique empirical correlation between these parameters cannot be obtained 


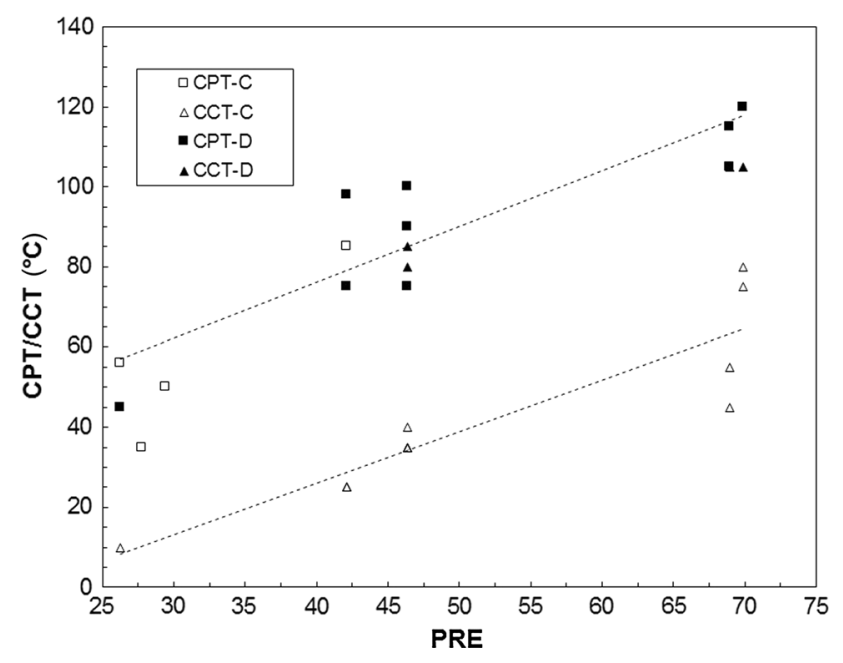

Fig. 1 Correlation between PRE, CPT and CCT of Ni alloys determined in ferric chloride solution ${ }^{\mathrm{C}}$ and in green death solution ${ }^{\mathrm{D}}$

for Ni alloys. As shown in Fig. 1, alloys having similar PRE might perform very different depending upon the testing environment. This can also be attributed to microstructural particularities in Ni alloys that are completely absent when considering solely the chemical composition in the calculation of PRE. Nevertheless, the results included in Table 3 clearly confirm that $\mathrm{Cr}$ and Mo are crucial for the localized corrosion resistance of $\mathrm{Ni}$ alloys.

\section{Upstream Oilfield Environments}

$\mathrm{Ni}$ alloys, especially those having high strength such as precipitation-hardenable $(\mathrm{PH})$ alloys, are widely used in oilfield technology preferentially in hot downhole environments that involve corrosive gases such as $\mathrm{CO}_{2}$ and $\mathrm{H}_{2} \mathrm{~S}$. In spite of its low PRE, the PH alloy 718 (UNS N07718) having high strength, excellent thermal stability and good corrosion resistance is very popular in the upstream oil and gas industry, mainly because downhole applications are often totally deaerated [50]. However, $\mathrm{Ni}$ alloys can be prone to localized corrosion also at oxygenfree conditions. Alloy 718 in age-hardened condition was determined being susceptible to pitting corrosion, for instance, in deaerated $4 \mathrm{~mol} / \mathrm{L} \mathrm{Cl}$-containing solutions of pH 6 at $150{ }^{\circ} \mathrm{C}$ [39]. A higher breakdown potential was reported at $150{ }^{\circ} \mathrm{C}$ in environments with the same chloride content when the $\mathrm{pH}$ of the fluid was raised to 10 . However, once localized corrosion initiated in the solution of $\mathrm{pH} 10$, the repassivation potential was less noble than the open circuit potential. This indicates that once pitting corrosion nucleates, the bulk $\mathrm{pH}$ of the solution has little or no influence in the repassivation potential value and pit propagation is mainly driven by the chemistry at the pit bottom, which is in agreement with Galvele's acidification model [43].

It is believed that microstructural particularities of $\mathrm{Ni}$ alloys also play a role on their localized corrosion resistance. Golenishcheva et al. [16] studied the effect of delta phase on the pitting corrosion resistance of oil patch alloy 718. The same chemistry of material was aged at two conditions: $8 \mathrm{~h}$ at $760{ }^{\circ} \mathrm{C}$ and $8 \mathrm{~h}$ at $870{ }^{\circ} \mathrm{C}$ followed by air cooling. They reported that material being heat treated at $870{ }^{\circ} \mathrm{C}$ having a higher content of delta phase was in general more susceptible to localized corrosion, with a lower breakdown potential. Chen et al. [33] also studied the pitting susceptibility of solution-annealed and age-hardened oil grade alloy 718 in $3.5 \% \mathrm{NaCl}$ solutions at room temperature using immersion tests and electrochemical techniques. Two heat treatments were used: one step of $788^{\circ} \mathrm{C}$ for $8 \mathrm{~h}$ and two steps of $760{ }^{\circ} \mathrm{C}$ for $5 \mathrm{~h}$ followed by $650{ }^{\circ} \mathrm{C}$ for $5 \mathrm{~h}$. After 7-day immersion in $3.5 \mathrm{wt} \% \mathrm{NaCl}$ solution, they found that the largest amount of corrosion pits were found in the one-step aging coupons and the lowest amount of pits were for the solution-annealed coupons. Chen et al. argued that the thermally formed strengthening precipitates were more noble to the gamma matrix, therefore forming microgalvanic couples which caused the pit nucleation. Electrochemical testing showed that the highest general corrosion rate also corresponded to the one-step aged sample and the lowest corrosion rate to the solution-annealed sample. After the anodic polarization, the one-step aged specimen had a higher density and larger corrosion pits than the two-step aged specimen. The solution-annealed specimen had few and isolated small pits. The results of the immersion tests obtained by Chen et al. [39], however, contrast with the well-documented excellent pitting corrosion resistance of alloy 718 in deaerated chloride-containing solutions at room temperature. Electrochemical and immersion tests were conducted by Mishra et al. [41] to determine the localized corrosion resistance of alloys 718, 625 and C-22HS (UNS N07022). Alloys 718 and C-22HS were tested being in annealed and age-hardened conditions. Examinations were performed in deaerated $\mathrm{H}_{2} \mathrm{~S}$-free $5 \% \mathrm{NaCl}+0.5 \%$ acetic acid solution according to NACE TM0177 [51], in acidified ferric chloride solution according to ASTM G48 [48], and in 3.5 $w t \% \mathrm{NaCl}$ solution at different temperatures. Alloy C-22HS was remarkably more resistant to localized corrosion than alloys 718 and 625 . The better localized corrosion performance of alloy C-22HS was attributed to its significant higher Mo content compared to alloys 718 and 625 (Table 3). The obtained values for CPT and CCT in acidified ferric chloride solution for initiation of stable pits and crevice attack on alloy 718 were similar for mill-annealed and for age-hardened specimens, however, the extent of corrosion damage was higher for the age- 
hardened compared to mill-annealed specimens for all the studied alloys. Electrochemical tests results also demonstrated a superior crevice corrosion performance of alloy C-22HS over alloys 718 and 625 .

$\mathrm{Ni}$ alloys are also preferred in downhole environments that involve hydrogen sulfide $\left(\mathrm{H}_{2} \mathrm{~S}\right)$. Rhodes et al. [24] mention that the presence of hydrogen sulfide in upstream environments may increase the pitting susceptibility of CRA in chloride environments. They also mention that there is a synergistic effect between pitting and cracking susceptibility since pitting may need to be established first before cracking nucleates. Yin et al. [30] established by electrochemical measurements that hydrogen sulfide acts as a cathodic depolarizer, thus accelerating localized corrosion of $\mathrm{Ni}$ alloys in $\mathrm{CO}_{2} / \mathrm{H}_{2} \mathrm{~S}$-containing environments.

\section{Seawater Applications}

Materials for seawater service were customarily associated with the ship industry. $\mathrm{Ni}-\mathrm{Cu}$ alloys are widely used in components subjected to flowing seawater but might experience pitting corrosion in stagnant seawater [3]. In present time, seawater service, however, is more associated with the oil and gas offshore industry and subsea applications, or desalinization plants. For non-cathodically protected seawater service, alloys with a PRE higher than 40 are preferred. In the offshore oil and gas industry, materials selection criteria are traditionally based on ISO 21457 [52] or NORSOK M-001 [53] standards which define materials resistant to seawater as those with a PRE higher than 40 . Consequently, the use of materials alloys with $\operatorname{PRE}<40$, even if Ni-based, is not recommended for subsea applications without cathodic protection [11].

Alves and Schmitz-Niederau performed 9-week immersion tests at 50 and $75{ }^{\circ} \mathrm{C}$ for several alloys in artificial seawater and in seawater containing $3 \mathrm{mg} / \mathrm{L}$ of chlorine [26]. The tested materials included the $\mathrm{Ni}$ alloys $825,625, \mathrm{C}-276$ and 59 . At $50{ }^{\circ} \mathrm{C}$, in the non-chlorinated seawater none of the materials suffered crevice corrosion and in the chlorinated seawater only alloys 825, 926 (UNS N08926) and C-276 suffered crevice corrosion. At $75{ }^{\circ} \mathrm{C}$, in non-chlorinated seawater only alloys 825 and 625 suffered crevice corrosion but in the chlorinated seawater four alloys: 825, 926, 625 and 31 (UNS N08031) suffered crevice corrosion. Only alloys C-276 and 59 were free from crevice corrosion at $75{ }^{\circ} \mathrm{C}$ in chlorinated seawater. The findings of Alves and Schmitz-Niederau agree well with the correlation between susceptibility to localized corrosion and the PRE of the tested materials (Table 3). On the other hand, Iannuzzi et al. [11] performed electrochemical testing at ambient temperature in $3.5 \mathrm{wt} \% \mathrm{NaCl}$ solution and reported that no clear correlation existed between the repassivation potential for localized corrosion and the PRE of the alloy. They recommended that materials selection for seawater applications should not be based on PRE alone. It was argued that the PRE includes information about what elements and in what amount they are present in the alloy but it does not specify the manner these elements are distributed in the alloy (e.g., solid solution vs. precipitated in a second phase compound) [11].

Birn et al. used potentiostatic and potentiodynamic methods to study the localized corrosion behavior of three $\mathrm{Ni}$ alloys: CR-2 $(20.9 \mathrm{Cr}+6.3 \mathrm{Mo}, \quad \mathrm{PRE}=42), \quad \mathrm{NI}-3$ $(26.8 \mathrm{Cr}+3.5 \mathrm{Mo}, \quad \mathrm{PRE}=38), \quad$ and $\mathrm{NI}-1$ $(15.7 \mathrm{Cr}+15.6 \mathrm{Mo}, \mathrm{PRE}=73)[18]$. The tests were performed in deaerated electrolytes of $0.5 \mathrm{~mol} / \mathrm{L}$ sulfuric acid with additions of sodium chloride up to $2 \mathrm{~mol} / \mathrm{L}$ concentration. Test temperatures were 25,50 , and $75^{\circ} \mathrm{C}$. Also experiments were performed in natural seawater of the Baltic Sea near Gdansk. After exposure of approximately 10 weeks in flowing seawater, none of the three alloys suffered pitting corrosion. However, the three alloys suffered crevice corrosion in natural seawater. Electrochemical tests showed that the alloy NI-1 was resistant to pitting corrosion in the sulfuric acid solution with $2 \mathrm{~mol} / \mathrm{L} \mathrm{NaCl}$ at the three tested temperatures. The other two alloys NI-3 and CR-2 having lower PRE suffered pitting corrosion under similar testing conditions.

Hibner and Shoemaker tested wrought and welded alloys C-276, 625 and 686 in quiescent seawater at $25{ }^{\circ} \mathrm{C}$ for 60 days [19]. At the end of the test period, both alloys C-276 and 686 were free from crevice corrosion, while alloy 625 did suffer crevice corrosion. Vinyl-sleeved tubes of the three alloys were also tested in flowing seawater at $14{ }^{\circ} \mathrm{C}$ for 180 days, and again, alloys C-276 and 686 were free from crevice corrosion, while alloy 625 corroded to a maximum depth of $0.11 \mathrm{~mm}$. Age-hardened alloys 725 (UNS N07725) and 625 were creviced with acrylic plastic devices and tested in quiescent seawater at $30^{\circ} \mathrm{C}$ for 30 days. Results show that alloy 725 was free from attack, but alloy 625 suffered crevice corrosion to a depth of $0.66 \mathrm{~mm}$. Age-hardened alloys 725 and 625 were also tested in flowing seawater at $14{ }^{\circ} \mathrm{C}$ for 180 days. Alloy 625 had crevice corrosion to a depth of $0.78 \mathrm{~mm}$, and alloy 725 had some minor crevice corrosion to a depth of only $40 \mu \mathrm{m}$. Hibner and Shoemaker did not explain the better resistance of 725 over 625 to localized corrosion, since they both have similar PRE (Table 3). Sridhar et al. [21] stated that if crevice corrosion occurs in seawater for alloys with PRE $>40$, it would be shallow, confirming the findings from Hibner and Shoemaker [19]. Sridhar et al. [21] pointed out that, regardless of PRE, localized corrosion is expected to initiate on a $\mathrm{Ni}$ alloy in seawater whenever the corrosion potential or open circuit potential is above the repassivation potential. Sugahara and Takizawa [16] 
performed corrosion tests in concentrated seawater simulating the conditions of desalinization plants containing from $1.8 \%$ to $22 \%$ chloride ions (of mixed salts $\mathrm{NaCl}$, $\mathrm{CaCl}_{2}, \mathrm{MgCl}_{2}$ and $\mathrm{KCl}$ ) at $100{ }^{\circ} \mathrm{C}$. They tested weld and wrought nickel alloys C-276 and alloy T21 for 17 days and found that alloy T21 (UNS N06210) was resistant to pitting corrosion in all the tested conditions. However, C-276 filler metal suffered pitting corrosion in the $18.9 \%$ chloride solution, and welded and wrought alloy C-276 suffered pitting corrosion in the $22 \%$ chloride solution.

\section{Chemical Process Industry (CPI)}

Highly aggressive environments are generally found in the CPI, often containing hot and concentrated streams of acids and salts that overexert the general and localized corrosion resistance of $\mathrm{Fe}$ alloys. Because of their outstanding corrosion resistance, $\mathrm{Ni}$ alloys are often selected to manufacture equipment in the CPI. Ni-Mo-alloys are generally used to handle pure reducing acids up to $70{ }^{\circ} \mathrm{C}$. $\mathrm{Ni}-\mathrm{Cr}-\mathrm{Mo}$ alloys are preferred where oxidizing conditions are present. The so-called C-family consisting in Ni-Cr-Mo alloys are multipurpose alloys widely used in the CPI. Alloy C-276, for instance, will perform relatively well in caustic solutions $(59 \% \mathrm{Ni})$, hydrochloric acid $(16 \% \mathrm{Mo})$ and hydrofluoric acid. Due to its versatility, it can be used to fabricate a vessel or heat exchanger that may be used interchangeable in several streams. Nevertheless, if the equipment will be used only to handle a particular environment, for example hot caustic solutions, alloy C-726 may not be the first choice; in this case, the alloy of choice will be Ni-200. The presence of oxidizing species and contaminants might limit the performance of $\mathrm{Ni}$ alloys in reducing environments. Hydrofluoric acid is commonly found in the CPI. It is a by-product from phosphoric acid production via wet process, and it is used as a fluorinating agent. Alloy 400 is typically used for handling aqueous hydrofluoric acid. However, in the presence of oxygen this alloy is susceptible to accelerated intergranular attack and SCC [3, 54]. Detailed information about Ni alloys selection for the CPI environments is given elsewhere [3, 31, 54].

Localized corrosion is the most common failure mechanism in the CPI [3]. Also the CPI generally rates the resistance to localized corrosion of alloys by using the PRE as well as the critical pitting and crevice temperatures [31]. Voigt et al. [17] determined the CPT of several Ni-based CRA by potentiostatic holding at $+0.2 \mathrm{~V}_{\mathrm{SCE}}$ in a $4.5 \mathrm{~mol} / \mathrm{L}$ $\mathrm{CaCl}_{2}$ solution. They reported that the CPT increased as the PRE of the alloy increased. It has to be noted that the equation used by Voigt to calculate the PRE does not include the effect of $\mathrm{W}$. Also the green death solution $\left(11.5 \% \mathrm{H}_{2} \mathrm{SO}_{4}+1.2 \% \mathrm{HCl}+1 \% \mathrm{FeCl}_{3}+1 \% \mathrm{CuCl}_{2}\right)$ is commonly used for the determination of CPT and CCT of $\mathrm{Ni}$ alloys used in the CPI (Table 3). Sugahara and Isobe reported that welded coupons of alloy T21 were resistant to pitting corrosion in the green death solution at $104{ }^{\circ} \mathrm{C}$ while the weld seam of C-276 suffered pitting [22]. The good localized corrosion resistance of T21 was attributed to the presence of tantalum in the alloy, which may enhance the protectiveness of the passive film [27]. Crook et al. [28] reported that alloy Hy-BC (UNS N10362) was also resistant to pitting corrosion in the green death solution at the maximum temperature of $120^{\circ} \mathrm{C}$.

Rajeswari et al. [32] studied the pitting corrosion behavior of type 316L stainless steel (UNS S31603) and the $\mathrm{Ni}$ alloys $825, \mathrm{C}-276$ and 59 in white water solution typical of the paper industry. The chloride and sulfate concentration was $1000 \mathrm{ppm}$ for each anion, while the $\mathrm{pH}$ of the solution was 3.5 and the temperature was set at $55{ }^{\circ} \mathrm{C}$. They performed potentiodynamic anodic polarization measurements and observed high breakdown potentials, 844 and $868 \mathrm{mV}_{\mathrm{SCE}}$, for alloys C-276 and 59, respectively. In addition, no significant hysteresis during the cathodic polarization scan was determined. The observed high values for the repassivation potential were just a curiosity since no localized corrosion was observed on these alloys. It has been observed that $\mathrm{Ni}$ alloys might undergo transpassive dissolution rather than pitting corrosion in high chloride-bearing environments at mild temperatures during potentiodynamic tests due to the high polarization potentials necessary to generate a significant increase in the current density [35, 39]. In contrast, Rajeswari et al. [32] confirmed that the stainless steel grade 316L and the Ni alloy 825 have suffered pitting corrosion in the white water solution after the cyclic polarization scan.

\section{Conclusions}

1. Ni alloys are produced by dissolving alloying elements into a $\mathrm{Ni}$ gamma matrix. The most common alloying elements are $\mathrm{Cr}$ and Mo. In contrast to $\mathrm{Fe}$ alloys, $\mathrm{Ni}$ can dissolve larger contents of beneficial alloying elements such as Mo without precipitating secondary phases. Therefore, Ni alloys have superior localized corrosion resistance compared to $\mathrm{Fe}$ alloys.

2. Both $\mathrm{Cr}$ and Mo provide $\mathrm{Ni}$ alloys with resistance to localized corrosion. The higher the $\mathrm{Cr}$ and Mo contents in the alloy, the better its localized corrosion resistance. Therefore, the resistance of $\mathrm{Ni}$ alloys to localized corrosion can, in general, be benchmarked using PRE regardless of the particular equation used for calculating it. The PRE being only based on the chemical composition, however, cannot be used to 
predict the localized corrosion resistance of these alloys at service conditions.

3. The presence of $\mathrm{Cr}$ in the $\mathrm{Ni}$ alloys may control the initiation to pitting corrosion, but it is the Mo content which appears to control the repassivation ability of the material. The repassivation behavior is crucial for the localized corrosion resistance particularly under crevice conditions.

\section{References}

[1] R.B. Rebak, Crystalline Alloys: Nickel, in Environmental Degradation of Advanced and Traditional Engineering Materials (London: CRC Press, 2013)

[2] Z. Szklarska-Smialowska, Pitting and Crevice Corrosion (Houston, TX, NACE, 2005)

[3] D.C. Agarwal, J. Kloewer, Nickel Base Alloys: Corrosion Challenges in the New Millennium, CORROSION/2001, Paper No. 01325 (Houston, TX: NACE, 2001), p. 1

[4] R.M. Carranza, M.A. Rodriguez, R.B. Rebak, Corrosion 63, 480 (2007)

[5] R.M. Carranza, JOM 60, 58 (2008)

[6] S. Sosa Haudet, M.A. Rodriguez, R.M. Carranza, R.B. Rebak, Effect of Alloy Composition on the Crevice Corrosion Resistance of Nickel Alloys, CORROSION/2012, Paper No. 01455 (Houston, TX: NACE, 2012), p. 1

[7] M.A. Rodriguez, Corros. Rev. 30, 19 (2012)

[8] N.S. Zadorozne, C.M. Giordano, M.A. Rodríguez, R.M. Carranza, R.B. Rebak, Electrochim. Acta 76, 94 (2012)

[9] M. Rincon Ortiz, M.A. Rodriguez, R.M. Carranza, J. Electrochem. Soc. 159, C469 (2012)

[10] M. Rincon Ortiz, M.A. Rodríguez, R.M. Carranza, R.B. Rebak, Corros. Sci. 68, 72 (2013)

[11] M. Iannuzzi, M. Rincon Ortiz, M. Kappes, M.A. Rodriguez, R.M. Carranza, R.B. Rebak, Selecting corrosion resistant alloys for seawater applications. CORROSION/2014, Research in Progress Symposium (Houston, TX: NACE, 2014)

[12] E.C. Hornus, C.M. Giordano, M.A. Rodríguez, R.M. Carranza, R.B. Rebak, J. Electrochem. Soc. 162, C105 (2015)

[13] M. Miyagusuku, R.M. Carranza, R.B. Rebak, Corrosion 71, 574 (2015)

[14] S.J. Mulford, D. Tromans, Corrosion 44, 891 (1988)

[15] K.A. Gruss, G.A. Cragnolino, D.S. Dunn, N. Shridhar, Repassivation Potential for Localized Corrosion of Alloys 625 and C22 in Simulated Repository Environments. U.S. Nuclear Regulatory Commission (Washington, D.C.) and Center for Nuclear Waste Regulatory Analyses, Southwest Research Institute (San Antonio,TX), 1998

[16] K. Sugahara, Y. Takizawa, Localized Corrosion Resistance of Corrosion-resistant Nickel Based Alloys in Hot Concentrated Seawater. CORROSION/1998, Paper No. 00697 (Houston, TX: NACE, 1998), p. 1

[17] C. Voigt, G. Riedel, H. Werner, M. Koehler, Mater. Corros. 49, 489 (1998)

[18] J. Birn, M. Janik-Czachor, A. Wolowik, A. Szummer, Corrosion 55, 977 (1999)

[19] E.L Hibner, L.E. Shoemaker, The Advantages of Nickel Alloys for Seawater Service. CORROSION/2000, Paper No. 00629 (Houston, TX: NACE, 2000), p. 1
[20] B.A. Kehler, G.O. Ilevbare, J.R. Scully, Corrosion 57, 1042 (2001)

[21] N. Sridhar, C.S. Brossia, D.S. Dunn, A. Anderko, Corrosion 60, 916 (2004)

[22] K. Sugahara, T. Isobe, Corrosion Resistance of the Ni-Cr-Mo-Ta Alloy (UNS N06210) in Waste Treatment Facility Simulated Environment Solutions. CORROSION/2005, Paper No. 05315 (Houston, TX: NACE, 2005), p. 1

[23] J.R. Hayes, J.J. Gray, A.W. Szmodis, C.A. Orme, Corrosion 62, 491 (2006)

[24] P.R. Rhodes, L.A. Skogsberg, R.N. Tuttle, Corrosion 63, 63 (2007)

[25] R.B. Rebak, Mechanisms of Inhibition of Crevice Corrosion in Alloy 22, paper NN8.4 in proceedings of the Materials Research Society Symposium, Vol. 985, p. 261 (2007)

[26] H. Alves, M. Schmitz-Niederau, Successful Applications of Nickel Alloys and High Alloyed Stainless Steels in Seawater Service. CORROSION/2008, Paper No. 08259 (Houston, TX: NACE, 2008), p. 1

[27] K. Sugahara, Beneficial Effects of Tantalum in Ni-Cr-Mo-Ta Alloy UNS N06210 CORROSION/2008, Paper No. 08182 (Houston, TX: NACE, 2008), p. 1

[28] P. Crook, N.S. Meck, N.E. Koon, The Corrosion Characteristics of a Uniquely Versatile Nickel Alloy. CORROSION/2008, Paper No. 08190 (Houston, TX: NACE, 2008), p. 1

[29] A.K. Mishra, G.S. Frankel, Corrosion 64, 836 (2008)

[30] Z.F. Yin, W.Z. Zhao, W.Y. Lai, X.H. Zhao, Corros. Sci. 51, 1702 (2009)

[31] H. Alves, R. Behrens, L. Paul, Review of Corrosion Issues and Materials Solutions in the CPI. CORROSION/2010, Paper No. 10338 (Houston, TX: NACE, 2010), p. 1

[32] S. Rajeswari, K.S.K. Danadurai, T.M. Sridhar, S.V. Narasimhan, Corrosion 57, 465 (2011)

[33] T. Chen, X. Liu, H. John, J. Xu, J. Hawk, Effect of Aging Treatment on Pitting Corrosion Behavior of Oil-grade Nickel Base Alloy 718 in 3.5 wt\% NaCl Solution. CORROSION/2012, Paper No. 01263 (Houston, TX: NACE, 2012), p. 1

[34] J.J. Debarbadillo, S.K. Mannan, JOM 64, 265 (2012)

[35] H. Sarmiento Klapper, R. Baessler, K. Weidauer, D. Stuerzbecher, Corrosion 68, 16001-1 (2012)

[36] A.K. Mishra, D.W. Shoesmith, Electrochim. Acta 102, 328 (2013)

[37] S. Schmigalla, A. Heyn, Mater. Corros. 64, 700 (2013)

[38] A.K. Mishra, D.W. Shoesmith, Corrosion 70, 721 (2014)

[39] H. Sarmiento Klapper, J. Stevens, Corrosion 70, 899 (2014)

[40] O. Golenishcheva, M. Oechsner, A. Aghajani, G. Andersohn, J. Kloewer, Influence of Delta-phase Precipitation on the Pitting Performance of UNS N07718, CORROSION/2014, Paper No. 03895 (Houston, TX: NACE, 2014), p. 1

[41] A. Mishra, D. Richesin, R.B. Rebak, Localized Corrosion Study of Ni-Cr-Mo Alloys for Oil and Gas Applications, CORROSION/2015, Paper No. 05802, (Houston, TX: NACE, 2015), p. 1

[42] A. Mishra, X. Zhang, D. Shoesmith, Corrosion 72, 356 (2016)

[43] J.R. Galvele, J. Electrochem. Soc. 123, 464 (1976)

[44] M. Speidel, Metall. Trans. 12, 779 (1981)

[45] ANSI/NACE MR0175/ISO 15156 Petroleum and natural gas industries-Materials for use in $\mathrm{H}_{2} \mathrm{~S}$-containing environments in oil and gas production, Section 6.3, (ANSI/NACE/ISO), 2009

[46] D.C. Agarwal, W.R. Herda, Mater. Corros. 48, 542 (1997)

[47] E. Hibner, S. Tassen, J.W. Skogsberg, Effect of Alloy Nickel Content vs. PRE on the Selection of Austenitic Oil Country Tubular Goods for Sour Gas Service. CORROSION/1998, Paper No. 106 (Houston, TX: NACE, 1998), p. 1

[48] ASTM G48-Standard Test Methods for Pitting and Crevice Corrosion Resistance of Stainless Steels and Related Alloys by 
Use of Ferric Chloride Solution, (West Conshohocken, PA: ASTM International)

[49] H. Sarmiento Klapper, R. Rebak, Corrosion 73, (2017) in press

[50] J. Kolts, Alloy 718 for the Oil and Gas Industry, Superalloy 718-Metallurgy and Applications, (The Minerals, Metals \& Materials Society, 1989), p. 329

[51] TM0177-Laboratory Testing of Metals for Resistance to Sulfide Stress Cracking and Stress Corrosion Cracking in $\mathrm{H}_{2} \mathrm{~S}$ Environments, (Houston, TX: NACE International)

[52] ISO 21457-Petroleum, petrochemical and natural gas industries-Materials selection and corrosion control for oil and gas production systems, (Geneva, Switzerland: International Organization for Standardization)

[53] NORSOK M-001 - Materials Selection, (Majorstuen, Norway: Norwegian Technology Center)

[54] R.B. Rebak, P. Crook, Influence of Alloying Elements, Temperature and Electrolyte Composition on the Corrosion Behavior of Nickel Based Alloys. CORROSION/2000, Paper No. 00499 (Houston, TX: NACE, 2000), p. 1 